\title{
Improving EFL Learners' Speaking Skill: The Role of Proficiency Level and L1
}

\author{
Elham Mohammadi \\ University of Zanjan, Zanjan, Iran
}

\begin{abstract}
The role of first language as an impediment to L2 learning has been a well-documented subject in second language research. Along the same line teachers prefer to use circumlocution instead of giving the students L1 translation of unknown words. The current study attempts to investigate the role of L1 translation tasks and the proficiency level in EFL learners' speaking performance. To this aim, 120 learners were selected and divided into control and experimental groups. All the participants received the same treatment in terms of time, materials and drills. However the experimental group received additional tasks including L1 translation. Subsequently they took part in two speaking tests and their results were analyzed using descriptive statistics and independent-sample t-test. No moderating effect for proficiency level was found and L1 translations tasks were revealed to be effective across both experimental groups of pre-intermediate and intermediate learners.
\end{abstract}

Index Terms - Translation tasks, EFL learners, speaking skill, Proficiency level

\section{INTRODUCTION}

Translation has always been one of the controversies on whether it can be an effective and valid tool in foreign language learning. Up to now, translation was not viewed as favor with the language teaching community. As a language learning activity, it was considered inappropriate within the context of English language teaching (Brown, 2002). It was criticized due to the close association with Grammar Translation Method (GTM). Even today translation is regarded as a kind of mechanical linguistic transfer of meaning from one language to another (Dagiliené, 2012). Translation is considered as time-consuming, boring, and irrelevant. Some like Harbord (1992) and Gorusch (1998) totally reject the use of first language and translation in the classroom. Despite having no theoretical and practical foundation to support its use (Richards \& Rodgers, 1986, p. 4), it is still employed in languge classrooms around the world. Particularly the twentieth century saw many theoretical works and practical methods in language teaching recommending to teach a second/foreign language without reference to the learners' first language (L1). There is a widespead belief among teachers that L1 translation hinders the acquisition of L2 (Liao, 2006). Furthermore teaching methods that were later developed (i.e Direct Method and Audio-Lingual Method) forbid translation and disregard its application in classroom activities.However, in the recent decades there has been a growing interest in the use of translation in the foreign language classroom and foreign language teachers begin to notice the pedagogical value of using translation along with other traditional language teaching activities; Reading, grammar exercises, translation — "are in fact perceived by learners to be conductive to learning" (McDonough, 2002, p.409). The use of second language is recommended during all types of activities (functional, authentic, and communicative) in CLT (Communicative Language Teaching) approach and students' native language plays no particular role in the classroom. Teachers in this approach assume that it is only through thinking in the second language and not translating nor reprocessing the target language into one's native language that learners can obtain native-like control of the language they are acquiring.

While there have been many theoretical arguments both for and against the use of L1 in the L2 classroom, a few studies were carried out to measure the exact effects of L1 to L2 translation tasks in English as a foreign language (EFL) classrooms. It seems that the difficult nature of measuring and gathering evidence in an attempt to answer such a difficult question can be the reason behind this. Therefore, not only must a valid and reliable way of assessing and measuring student learning be established, but at least two languages must be used correctly and clearly in the classroom as well. 
Assessing the effects of using L1 on learning L2 is fairly complicated. One of the ways of assessing the impacts of L1 on learning is to control all the other influential variables, and then to measure the improvement of the respective foreign language learners. If a student learning can be attributed directly to the use of L1, then a strong case can be made in favor of using L1 in the language classroom. The problem addressed in the present study is the relevance of translation for enhancing foreign language skills. It aims to prove that translation is a valid method for language practice and improvement. The main objective of the study is to investigate the impacts of L1 to L2 translation tasks on improving pre-intermediate and intermediate second language learners' speaking skill. To be more specific, the following research questions are raised:

1. Does the use of L1 to L2 translation tasks in EFL classrooms have any significant impacts on the preintermediate EFL learners' speaking fluency?

2. Does the use of L1 to L2 translation tasks in EFL classrooms have any significant impacts on intermediate EFL learners' speaking fluency?

\section{REVIEW OF LITERATURE}

Translation is understood differently by linguists, teachers, and methodologists. Its use in foreign language teaching led to a great deal of criticism and disagreement. One of the main reasons for this is during the last decades a number of studies were carried out, which have either completely ignored or favored the use of translation as a learning method. Briefly speaking the review of literature indicates that there is no agreement among language educators on the impacts of L1 to L2 translation tasks on language learners' fluency and accuracy in language skills, particularly speaking.

On one hand, some language educators forbid the use of L1 in L2 classrooms. For instance, Malmkjaer (1998) summarizes the main reasons why translation was not welcomed in EFL classrooms:

1. Translation is independent and radically different from the four skills which define language competence: reading, writing, speaking and listening.

2. Translation takes up valuable time which could be used to teach these four skills.

3. Translation is unnatural.

4. Translation misleads and prevents students from thinking in the foreign language.

5. Translation is a bad test of language skills.

6. Translation produces interference.

7. Translation is only appropriate for training translators.

Harbord (1992) provides some justification for not using translation in L2 teaching activities. He believes that the use of translation tasks means a return to Grammar-Translation Method with all of its negative connotations. He also believes that the isolation of lexis from any real context prevents students from gaining insight into the multiple uses and meanings of the word. He further contends that in an informal application, translation creates a situation in which the stronger students prevent weaker students from contributing to the L2 by enforcing a feeling of inferiority.Duff (1994) reveals further reasons why teachers declined to the use of translation in language classes. He stresses that translation is text-bound and confined only to reading and writing skills. It is not a communicative activity because it does not involve oral interaction. Furthermore, Gorusch (1998) explored 'yakudoku', a form of Grammar-Translation in theJapanese education system, noting the problems it had created. She found that a heavy reliance on translation was at the expense of any form of communication, and an apparent result was that the students focused the bulk of their attention on the Japanese translations of the English text, rather than the English text itself. Translation, in this case, was not put to the service of learning English, but was used to demonstrate knowledge of structure. All consideration of the text was carried out in Japanese.On the other hand, there are "significant and visible signs of a revival of translation in language teaching according to recent literature and applied linguistics" (Malmkjaer, 1998, p.1). There are many theorists, linguists who strongly believe in the importance of using translation in foreign language classes. They believe that there is no reason why translation activities cannot be incorporated into a communicatively based lesson, and, thus, promote different activities that suit the different goals and aims of language learners (Edge, 1986; Tudor, 1986; Atkinson, 1987; Heltai: 1989). For instance, Schaffner (1998) claims that the translation and related exercises could be beneficial to foreign language learning in improving verbal ability, expanding students' vocabulary in L2, improving the learners' understanding of how languages work, consolidating L2 structures for active use, and improving the comprehension of L2.In the same vein, Dagiliene (2012) argues that translation in foreign language classes is becoming a form of pedagogical translation, which is viewed as an effective tool in language learning and is evaluated as a way to enhance learners' competences. Students taught by using pedagogical translation are encouraged to practice reading, writing, vocabulary, grammar, and speaking. It is also argued that Translation heightens language awareness. While students are translating, they focus on identifying differences in vocabulary and structure. The real useful point in the application of translation in foreign language classes lies in the comparison of vocabulary, grammar, word order 
and other language points in the student's mother tongue and the target language. Students are exposed to contrasting language systems of the target and the native languages (Dagilienė, 2012).

Ross (2000) holds that translation is recognized as the fifth skill and the most important social skill because it promotes communication and understanding. As a form of communication, it involves interaction between people, which makes it a very useful tool in foreign language teaching.Heltai (1989) suggests a guideline for the use of translation, holding that it should be used when translation is an end in itself; when English is a foreign language and not a second language; with students at an advanced level of language ability; for adults who prefer conscious learning; when formal correctness is important and the students are actively interested in acquiring this formality; and when the teacher shares the same L1 as the students. While these scholars may disagree as to with whom and to why translation should be used, there is some consensus as to how it benefits students and to where it should be used, which is in classes where the L2 is a foreign language and there are few opportunities to experience that language outside the classroom situation.If the translation activities are done in pairs or in small groups, the students must use the target language for negotiation in order to agree on the more appropriate language to be used (Heltai, 1989; Edge, 1986). Atkinson (1987) suggests that activities that involve some translation promote guessing strategies amongst students and help reduce the wordfor- word translation that often occurs and which results in inappropriate L2 use. Even Harbord concedes that some translation work teaches students to work towards transferring meaning "rather than the word-for-word translation that occurs when the learner's unconscious need to make assumptions and correlations between languages is ignored" (Harbord, 1992, p. 354).While many foreign language educators may have ignored the role of translation in language teaching, from the learners' perspective, translation is still widely used in their learning (Naiman et al. 1978; Marti Viano \& Orquin 1982; Politzer 1983; O’Malley et al. 1985b; Chamot et al.1987). For instance, Naiman et al. (1978) aimed to identify strategies used by Good Language Learners (GLLs), and found that one of the strategies often used by GLLs was to "refer back to their native language(s) judiciously (translate into L1) and make effective cross-lingual comparisons at different stages of language learning" (p. 14). It appears that learners very often use translation as a learning strategy to comprehend, remember, and produce a foreign language. However, it seems that so far relatively little research attention has been devoted to a consideration of the impacts of translation tasks on learners' speaking fluency and the significance of translation from the learner's points of view or beliefs.

\section{METHOD}

\section{A. Design}

This was an experimental study. That is, there were both control and experimental groups. To make sure that there was no initial difference between experimental and control groups, a pre-test was administered to participants of each proficiency level. The experimental groups received a treatment. Finally, the participants of each proficiency level were given a post-test.

\section{B. Participants}

A total of 120 adult language learners (six classes) attending speaking courses in the last two years in language institutes in Ahwaz, Iran were selected. Half of the participants of the study were pre-intermediate and the rest were intermediate. 30 participants attended speaking courses in 2009, and the remaining participants attended speaking courses in 2010. Most participants were distributed across different university majors. The participants were relatively evenly distributed across the majors of biology, chemistry, Persian literature, nursing, mechanical engineering, computer, law, and mathematics. The participants of both control and experimental groups were taught interchange books. They all attended a 120- hour- speaking course. The same tasks, materials, and drills were used to teach all the groups. The only difference was that the participants of the experimental group received some oral L1 to L2 translation tasks. That is, the students were asked to give the English equivalents of some Persian sentences on the basis of contents of each lesson whereas the control groups were not provided with such types of tasks.

\section{Instruments}

Two different speaking tests consisting of the same production items and an interview checklist were used in this study. The items were selected from Interchange Books $1 \& 2$. Each test consisted of 10 essay items. The participants' responses to different items were recorded and evaluated by two different raters. Interrater reliability approach was applied to estimate the reliability of the tests. That is, the elicited production of each participant was evaluated by two different raters. The correlation coefficient between the two ratings for the pretest and the posttest was .87 and .85 , respectively, which were good reliability indices. 
D. Data analysis

The data of the study were analyzed through descriptive (mean, standard deviation, and variance) and inferential statistics. As for each proficiency level, there are only two independent groups, two independentsample $t$-tests were needed to analyze the data $(\mathrm{p}=.05)$.

\section{RESULTS}

The results of the descriptive statistics for pre-intermediate and intermediate language learners are presented in the following tables.

TABLE I.

DESCRIPTIVE STATISTICS FOR PRE-INTERMEDIATE LEARNERS

\begin{tabular}{|l|c|r|r|r|r|}
\hline & groups & \multicolumn{1}{c|}{$\mathrm{N}$} & \multicolumn{1}{c|}{ Mean } & Std. Deviation & Std. Error Mean \\
\hline \multirow{2}{*}{ scores } & experimental & 30 & 16.80 & .43 & .08 \\
\cline { 2 - 7 } & control & 30 & 12.20 & 1.5 & .28 \\
\hline
\end{tabular}

TABLE II.

INDEPENDENT SAMPLE T-TEST FOR PRE-INTERMEDIATE LEARNERS

\begin{tabular}{|c|c|c|c|c|c|c|c|}
\hline \multicolumn{2}{|c|}{} & $\begin{array}{c}\text { Levene's Test } \\
\text { for equality of } \\
\text { means }\end{array}$ & \multicolumn{5}{|c|}{ t-test for Equality of Means } \\
\cline { 2 - 7 } & $\mathrm{F}$ & Sig. & $\mathrm{t}$ & $\mathrm{df}$ & Sig. & Mean Difference \\
\hline scores & $\begin{array}{c}\text { Equal } \\
\text { variance } \\
\text { assumed }\end{array}$ & 1.2 & .274 & 16.48 & 58 & .001 & 4.96 \\
\cline { 2 - 7 } & $\begin{array}{c}\text { Equal } \\
\text { variance } \\
\text { not } \\
\text { assumed }\end{array}$ & & & 16.48 & 48 & .001 & 4.96 \\
\hline
\end{tabular}

As shown in Table 2, the p value of Leven's test is 0.27 , which exceeds the critical value of 0.05 . Therefore, the null hypothesis which indicated that there was no difference between the variance of the groups was confirmed, and it was safe to run an independent t-test to compare the means of the two groups. Moreover, the results indicate that there is a significant difference between the control and the experimental groups $(\mathrm{p}=0.001<0.05)$. That is, experimental group had outperformed the control group on the speaking test.

TABLE III.DESCRIPTIVE STATISTICS FOR INTERMEDIATE LEARNERS

\begin{tabular}{|l|l|l|l|l|l|}
\hline & $\mathrm{N}$ & Minimum & Maximum & Mean & Std. Deviation \\
\hline experimental & 30 & 16 & 18 & 16.80 & .48 \\
\hline control & 30 & 9 & 15 & 12.20 & 1.54 \\
\hline
\end{tabular}

TABLE IV. INDEPENDENT SAMPLE T-TEST FOR INTERMEDIATE GROUPS

\begin{tabular}{|c|c|c|c|c|c|c|c|}
\hline \multicolumn{2}{|c|}{} & \multicolumn{2}{|c|}{$\begin{array}{c}\text { Levene's Test } \\
\text { for equality of } \\
\text { means }\end{array}$} & \multicolumn{4}{|c|}{ t-test for Equality of Means } \\
\cline { 2 - 8 } & $\mathrm{F}$ & Sig. & $\mathrm{t}$ & $\mathrm{df}$ & Sig. & Mean Difference \\
\hline scores & $\begin{array}{c}\text { Equal } \\
\text { variance } \\
\text { assumed }\end{array}$ & 1.1 & .17 & 15.60 & 58 & .001 & 4.6 \\
\cline { 2 - 8 } & $\begin{array}{c}\text { Equal } \\
\text { variance not } \\
\text { assumed }\end{array}$ & & & 15.60 & 34 & .001 & 4.6 \\
\hline
\end{tabular}


As shown in Table 4, p value of Leven's test is 0.27 which exceeds the critical value of 0.05 . Therefore, the null hypothesis which indicated that there was no difference between the variance of the groups was confirmed, and it was safe to run an independent t-test to compare the means of the two groups. Moreover, the results indicate that there is a significant difference between the control and the experimental groups $(\mathrm{p}=$ $0.001<0.05)$. That is, experimental group had a better performance on the speaking test.

\section{V. DISCUSSION}

This study was an attempt to investigate the impacts of L1 to L2 translation tasks on improving Iranian pre-intermediate and intermediate language learners. The results in Tables 1, 2, 3, and 4 show that the mean scores of the experimental groups, both intermediate and intermediate, on speaking tests, which were evaluated in terms of fluency and accuracy, were significantly different from the control groups' mean scores. Therefore, it could be strongly argued that L1 to L2 translation tasks could be very influential in EFL classrooms. The findings of the present study are in line with Leonardi (2011) who argues that translation, as a pedagogical tool, can be successfully used at any level of proficiency, at university or school, as a valuable and creative teaching technique to support, integrate and strengthen the four language skills: reading, writing, speaking and listening. The results are also consistent with O'Malley et al. (1985) who believe that out of a total of 11 cognitive strategies identified by the researchers, translation accounted for $11.3 \%$ of all strategy uses by beginning and intermediate-level ESL learners. Therefore, translation can be identified as one of the cognitive and useful learning strategies. Moreover, the results are also in line with Kobayashi and Rinnert (1992), who found that Japanese college students who wrote English essays through Japanese translation were rated higher than those who wrote directly in English. As for the advantages of translating, the students felt that the ideas were easier to develop, thoughts and opinions could be expressed more clearly, and words could be more easily found through the use of a dictionary. In addition, translation also can help in vocabulary acquisition. Carefully analyzing the data of the present study and reviewing Prince's (1996) research results, one can reveal the superiority of using translation in speaking performance in terms of fluency and accuracy. It could also be argued that strategic learners can make intelligent use of the repertoire of their L1 skills and translation so that they can learn a new language more efficiently.The results of the study indicate that both intermediate and pre-intermediate language learners who were exposed to translation tasks had a better performance than those who did not benefit from such a task. Therefore, as Husain (1995) believes, it could be strongly argued that using translation can have highly positive effects on the low and intermediate proficiency learners. Also, it could be discussed that translation can serve as a problem-solving exercise as well as a cognitive exercise in the classroom. More importantly, the use of translation at the intermediate and pre-intermediate proficiency levels can help learners extend their knowledge of the foreign language by making reference to their mother tongue, and can help learners clarify the similarities and the differences between the foreign language and their native language.

\section{CONCLUDING REMARKS}

In line with the findings of the present study and the other related studies it could be concluded that as translation is viewed as a communicative activity, it involves interaction between the teachers and the students. Through translation, students are involved in a conversation on the translation tasks, which help them improve their speaking skills. Moreover, students while translating talk to both the teacher and other learners and through listening to the teachers and students improve their listening skills. When introduced purposefully into language learning program, translation can become an appropriate language practice method for many students. Furthermore, when integrated into daily classroom activities it can help students develop language skills and components. Translation contributes to better understanding of structures of the two languages. It is an effective tool in the foreign language learning and can be practiced in the university classrooms to improve knowledge in English. However, it should not be overused and translation activities should not be used in isolation, but should be integrated with different language learning processes. The scope of the present study was limited to the pre-intermediate and intermediate language learners. Therefore, the results should be generalized to language learners with different proficiency levels with great care. Therefore, It is not clearly known whether such a treatment can have any impacts on advanced language learners' speaking or not. The other researchers are welcomed to replicate the study using high proficient language learners and the other language skills such as writing.

\section{REFERENCES}

[1] Atkinson, D. (1987). The mother tongue in the classroom - a neglected resource? ELTJ, 41(4).

[2] Brown, H. D.(2002). Principles of Language Learning and Teaching. New York: Longman

[3] Chamot, A.U. (1987). The Learning strategies of ESL students, in A.L. Wenden and J. Rubin (eds.). Learners' strategies in language learning. (pp. 71-83). Englewood Cliffs, NJ: Prentice-Hall.

[4] Dagilienè, I. (2012). Translation as a learning method in English language teaching. Studies about languages, 21, 124-129. 
[5] Duff, A. (1994). Translation: Resource Books for Teachers. Oxford: Oxford University Press.

[6] Edge, J. (1986). Acquisition disappears in adultery: interaction in the translation classroom. ELTJ, 49(2).

[7] Gorusch, G.J., (1998). Yakudoku EFL instruction in two Japanese high school classrooms: An exploratory study. JALT journal 20(4).

[8] Harbord, J., (1992). The Use of the mother tongue in the classroom. ELTJ, 46(4).

[9] Heltai, P. (1989). Teaching vocabulary by translation. ELTJ, 43(4).

[10] Hubbard, P.L. (1994). Non-transformational theories of grammar: Implications for language teaching. Perspectives on pedagogical grammar. CUP.

[11] Husain, K. (1994). Translation in the ESL Classroom: Emerging Trends. International journal of translation, 1(2), $115-30$.

[12] Husain, K. (1995). Assessing the Role of Translation as a Learning Strategy in ESL. International journal of translation, 1(2), 59-84

[13] Leonardi, V. (2009). Teaching business English through translation. Journal of Language \& Translation, 10(1), 139153.

[14] Leonardi, V. (2011). Pedagogical translation as a naturally occurring cognitive and linguistic activity in foreign language learning. Annali Online di Lettere-Ferrara [online], vol. 1-2, p.17-28, available at: http://eprints.unife.it/annali/lettere/2011voll1-2/leonardi.pdf [Accessed 22/03/2013].

[15] Malmkjaer, K. (1998). Translation and language teaching. Manchester: St Jerome.

[16] Marti Viano, M.D., \& Orquin, V. (1982). Identifying our students' strategies for Learning English as a Foreign Language, Modern language teachers, 9 (4) 38-41.

[17] Naiman, N., Frohlich, M., Stern, H.H, \& Todesco, A. (1978). The good language learners. Ontario Institute for Studies in Education.

[18] O'Malley, J.M., et al. (1985). 'Learning strategies used by beginning and intermediate ESL students. Language learning, 35, 21-46.

[19] Politzer, R.L. (1983). An exploratory study of self-reported language learning behaviors and their relationship to achievement. Studies in second language acquisition, 6(1) 54-68.

[20] Posen, L. (2006). EFL learners' beliefs about and strategy use of translation in English learning. ERIC. Vol 37(2) 191-215 | DOI: $10.1177 / 0033688206067428$

[21] Prince, P. (1996). Second language vocabulary learning: The role of context versus translation as a function of proficiency. Modern language journal 80, 478- 93.

[22] Richards, J.C., \& Rodgers, T. (2000). Approaches and methods in language teaching. Cambridge University Publications.

[23] Ross, N. J. (2000). Interference and Intervention: Using Translation in the EFL Classroom. Modern English Teacher, 9(3), 61-66.

[24] Titford, C. (1985). Translation—a Post-communicative Activity for Advanced Learners', in C. Titford and A.E. Hiehe (eds.), Translation in foreign language teaching. (pp. 73-86).Tubingen, N.T. I. (1986). Using translation in E.S.P. ELTJ, 41(4). 